\title{
Church mothers of Mbare Township: In memory of Mrs Elizabeth Maria Ayema (Mai Musodzi) and Sr Barbara Tredgold
}

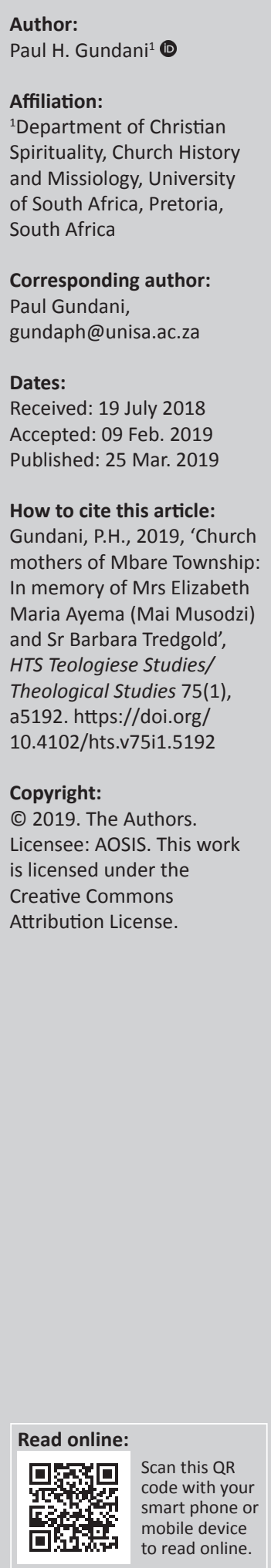

The changing of place names (e.g. street and public buildings) often accompanies change of governments, particularly in countries where one ideology has triumphed over another. This was the case in Zimbabwe following the triumph of ZANU-PF over the settler colonial government of Ian Smith, in 1980. Harari Township, the oldest black suburb in the then city of Salisbury (also renamed Harare), underwent name change in 1982 and was renamed Mbare. Public consultations by the City Council resulted in the changing of the street names that brought about a changeover in Township's ondonyms. Streets and public buildings were renamed after persons who had made outstanding contribution to the development of the Township. Among those honoured were two outstanding female Christian leaders, Mrs Elizabeth Maria Ayema (popularly known as Mai Musodzi) and Barbra Tredgold. Incidentally, these were the only two women after whom a street and a public amenity were named. In this article, we investigate the contribution that these two women made to Mbare Township to deserve the honour bequeathed on them by the residents of Mbare. In the article, we acknowledge that Mai Musodzi and Barbara Tredgold were honoured because they were among the illustrious leaders, who served the Township with distinction. By honouring their memory, residents of Mbare were, by implication, making a commitment to live by the values that the two stalwarts stood for. In our conclusion, we argue that the tribute accorded to the two reflects the consensus of the residents of Mbare that Christian values that the two had lived by were an important site of struggle for marginalised black people, who made the ghetto-like 'Location' a homely habitat.

\section{Introduction}

The renaming of streets and public amenities is a common practice following political upheavals. The purpose of renaming is often premised on the need to commemorate and celebrate heroes and heroines as well as the values pointing to the dawn of a new dispensation. According to Faraco and Murphy (1997):

Dramatic, transformative personal or social events are commonly marked by a change of names. The assumption of new names not only signals a significant change in social direction for individual or collectivity, it also reveals much about the nature of agency of that change. (p. 123)

This was true in the case of Rhodesia, which became independent in 1980. The ZANU-PF government, under the leadership of Robert Mugabe, embarked on a process of changing names of streets and public buildings or amenities soon after taking over power. Old names associated with the colonial past gave way to new names, affirming a new political and ideological identity. Similarly, colonial names on the streets and public utilities in townships across the country were also changed (Mushati 2013). In the case of Mbare, the oldest African Township in Zimbabwe, a similar naming or renaming process was also undertaken. However, what is striking is that of the many stalwarts whose names made it to the streets and public buildings, only two were women, that is, Mrs Elizabeth Maria Ayema (Mai Musodzi) and Sr Barbara Tredgold. This article was a result of the author's curiosity on the identity and contribution made by these two women to the development of Mbare Township. ${ }^{1}$ The article seeks to address two fundamental questions: firstly, what role did the two play in the life of Harari Township to deserve the honour of being remembered through the name changing of a street and a public utility? Secondly, what is the significance of the act of renaming for the residents of Mbare Township?

1.In the article, I use the less offensive term "Township" instead of the colonial term 'Location'.

Note: The collection entitled 'Christina Landman Festschrift', sub-edited by Wessel Bentley (University of South Africa) and Victor S. Molobi (University of South Africa). 


\section{Theory and method Changing of place names and memory}

The theoretical underpinning of this study is based on writings by Feraco and Murphy (1997), Guyot and Seethal (2012) and Mushati (2013). These scholars have researched name changing following political upheavals in Spain, South Africa and Zimbabwe, respectively. Guyot and Seethal (2012:53) contend that place names play an important role in the process of transforming a negative sense of place into a positive one. Therefore, the change of place names 'emphasises the question of memory of a past that new names want to rectify or to clear'. Similarly, Mushati (2013:70) argues that the act of street naming is 'an integral part of everyday communication since [street names] are used daily by residents and visitors to give directions as homes and institutions are located in specific streets'. Furthermore, Mushati (2013) interprets the naming or renaming of streets as:

... an act of speaking about and remembering shared experiences and values ... an ideal platform for formerly colonised subjects, who had hitherto been erased from history, to engage in counterdiscourses that authorise their presence. (p. 70)

Feraco and Murphy (1997:123) add nuance to the significance of name changing when they argue that '... naming systems also serve as mechanisms of social compensation for structural imbalances, thus inverting rather than mirroring important social principles'. They further observe that the naming of places '... reveals much about the nature and agency' of the change that the process signifies.

The findings made by the scholars, cited above, present us with sound theoretical underpinning for our study.

This article is a qualitative study mainly based on the evaluation of existing secondary sources. It utilises social, historical, cultural and ecclesiastical sources of life in Mbare Township during the colonial period. However, to enrich the study, the author reflects on some primary sources that he had at his disposal during his doctoral studies in the early 1990s.

The following format will thus be followed: firstly, we trace the origins and development of Mbare Township from 1907 to 1980; secondly, we interrogate the role and place of the church in the Township; thirdly, we present profiles of Mai Musodzi and Barbara Tredgold; and finally, we present our evaluation and conclusions.

\section{The birth and development of Mbare Township (1907-1980)}

The role and contribution of the two Christian women, after which a public building and a street were named, can only be understood within the broader social, cultural and political dynamics in the 'African Location'.

For ease of analysis, it is necessary to divide this section into subsections based on critical historical periods that distinguished the growth and development of Mbare Township.

\section{7-1930}

The origin of the Mbare Township dates back to the passing of the Native Urban Locations Ordinance (No. 4 of 1907) by the British South Africa Company (BSAC), ${ }^{2}$ which prohibited 'free residents' in Salisbury.

The Ordinance took effect in May 1908. The Ordinance required 'all Africans in Salisbury, except those already sleeping on employers' premises, to move to the "African Location", from May 1908'. It effectively made African residency in the town of Salisbury illegal (Yoshikuni 2007:9).

What was originally called the 'African Location' was later renamed Harari African Township in 1946 (Makombe 2013 xvii). The core area of the 'Location' was situated about 5 miles west of town centre, 'screened off by a railway line and trees, downstream and leeward of European habitation ... adjacent to the cemetery, the slaughter poles and sanitation works' (Yoshikuni 2007:31). Since 1908, the 'African Location' became the place for Africans who were evicted from town. According to Hallencreutz (1998):

It started as a small housing estate, with fifty Kaytor huts (made of circular, corrugated iron walls and thatched roofs), a brick barracks of four rooms, a well, communal latrines, and a refuse depot. (p. 29)

The houses were nicknamed 'Ma Tank' (i.e. tanks) by African residents. Since 1908, the 'Location' became home for Africans who kept their wives in the African Reserves. This policy changed in 1922 when the Salisbury Town Council introduced a section for married residents (Rakodi 1995:48).

\section{0-1945}

The attainment of self-government for Rhodesia in 1923 brought with it new priorities, especially on the issue of land management. As a result, the Land Apportionment Act (1930), which Hancock (1984:3) refers to as 'the cornerstone of white supremacy' in Rhodesia, brought about legislated segregation of land along lines of race. It divided up the country into three categories of land holding: land for Europeans, land for Africans and Crown land for game parks. The Land Apportionment Act (1930) was followed by the Land Husbandry Act (1941), which introduced freehold land ownership and limited the carrying capacity of stock on such land. The two legislations forced many Africans off land that was declared 'European', and pushed them to urban and industrial centres. As pressure mounted in the rural areas, more Africans moved to Salisbury and other towns. In response to the African influx in the 1930s, the Salisbury City Council took a decision to expand the 'Township' to the southeastern side of the original 'Location'.

2.The BSAC was the colonial administration in charge of Mashonaland since 1890 and Rhodesia between 1895 and 1923. 


\section{5-1980}

Soon after the Second World War (WWII), the government of Southern Rhodesia introduced more strident laws to enforce racial segregation in the city of Salisbury. In particular, the Native Urban Areas Accommodation Act of 1947 turned Salisbury into a 'White city'. According to Ranger (2013):

For a decade, Salisbury's counsellors had worked hard to ensure that all Africans lived in townships ${ }^{3}$ and not in the city; that African domestic servants should not be allowed to keep their families with them in suburbs; that facilities be strictly segregated; that 'elite' African be corralled into small areas on the margin of townships. (p. 15)

The Act provided impetus for the Salisbury Town Council to set up a department of African Administration that embarked on a construction programme of hostels, as well as some small family houses in Harari Township (Rakodi 1995:50).

In the mid-1950s, Harari African Township saw enormous expansion as the city of Salisbury benefited from an unprecedented influx by white migrants following the establishment of the Federation of Rhodesia and Nyasaland. City authorities took advantage of this demographic boon and took decisive steps to introduce the "White city" principle to Salisbury' (Yoshikuni 2007: 79). To create the 'White city', all Africans who were hitherto accommodated or traded in the city (except domestic workers) were forcibly evicted. Hence, the early 1950s saw new houses being constructed in what later became the 'National' section of the 'Township'.

By 1969, Harari Township 'accommodated over half of the African population within the municipal boundary (app. 60, 000 people)' (Rakodi 1995:50). Although the 'Township' was originally designated as a residence for African workers who were not wanted in town, the 1970s ushered in a new political and social dynamics that altered the original identity. Effects of the liberation struggle raging in the countryside forced rural people to move into the 'Township' seeking refuge. Rakodi (1995) has this to say about the change brought to bear on Harari Township by the drama taking place in the countryside of Zimbabwe:

By the mid-1970s, escalation of the struggle for independence led to an influx of refugees into the capital. A municipal transit camp was set up at Musika, the long distance bus station near Mbare (Harare), with temporary plastic and later concrete pole and panel dwellings for rent. To provide somewhere for people to go, the International Red Cross provided temporary relief housing of wood and sundried brick, with asbestos roof ... (pp. 52-53)

The Musika (i.e. market place) became a sanctuary for rural refugees who were forced by circumstances to live a life of vending in the rough and tumble of the Township environment.

In 1979, when the war of liberation ended, Harari Township had undergone unprecedented social, political, cultural and 3.Another African location, Highfields Township, was established in 1937. demographic transformation. It not only consisted of the 'Ma tank' (1908), 'Old bricks' (1922), 'Married Quarters' (1927), 'Jo'burg Lines/Majubheki' (1930s), 'Mahosteri (hostels)' (1950s) and 'National' (1950's), but was at the cusp of more drastic social change as the queues of unemployed became longer, and the influx of destitute and desperate rural refugees gathered pace. At the age of 72, Harari Township had gone full circle.

\section{From Harari African Township to Mbare high- density suburb (1982 and after)}

In 1982, change of place names was made by the Harare City Council in terms of Sections 96, 97 and 210 of the Urban Councils Act (Chapter 29 s.15). The change followed recommendations from the Environmental Management Committee, which oversaw the naming of suburbs, urban roads, streets and public amenities (http://www.hararecity.co.zw/). The name change was also introduced in line with the ruling ZANU-PF policy of renaming towns, local councils and residential places. ${ }^{4}$ As the city of Salisbury changed to become Harare, Harare Township was up for a new name. The new name Mbare, adopted in 1982, was in honour of Mbare, chief of the Korekore chiefdom, who ruled the territory encompassing the area where the town of Salisbury was located by Rhodes' BSAC pioneers, in 1890 (Makombe 2013:31). Following the public consultations with residents of the 'Township', streets, roads and public amenities were renamed. Those honoured and whose names were approved ranged from politicians, business people, war heroes and community leaders from the Township, among others (Jenje-Makwenda 2011). The names provide 'insight into how the people [of Harare township] lived and how much value they placed on their suburb and the people that made a difference there' (Kadirire 2014).

\section{Church life in Harari Township}

In this section, we briefly discuss the role and place of the church in the Township so as to situate the work and contribution of Mai Musodzi and Barbara Tredgold. Soon after the founding of Salisbury, in September 1890, churches such as the Anglican, Catholic and Methodist were given land grants by the BSA Company to establish centres of evangelisation. Although some churches were established in the Commonage, east of town, the Wesleyan Methodist Church also set up an extensive compound on the southwestern periphery of the town. According to Hallencreutz (1998:30), the compound provided a safe haven for Methodists migrating into Salisbury town. In Hallencreutz's view, the Methodist compound became 'the cradle of African Christianity in Harare' (1998). Hallencreutz further argues that:

From the beginning, the emerging local congregation was nurtured by African missionaries, mostly Josiah Ramushu ... and later Samuel Tutani. From 1894 (when the foundation stone of the church was laid), [Rev.] John White was in charge of the work. (p. 30)

4.This was consistent with the Place Names Commission that was set up under the auspices of the National Monuments Committee. 
Although the Methodist Compound was out of the original 'African Location', it became part of the Church reserve in 1909 (Yoshikuni 2007:38) and subsequently became an integral part of the 'Location'.

In 1909, the Catholic Church was allocated land to build a church within the Church reserve. Subsequently, St. Peter's Roman Catholic Church was opened up for worship in 1911 (Hallencreutz 1998:27). In 1910, the Dutch Reformed Church Mission built a church in the reserve for Malawian migrants. The latter became the Church of Central Africa-Presbyterian (CCAP):

By 1910 the churches were all placed around the official location, except the Anglican St Michael's to the east of town. As a result, church-goers and school pupils were increasingly lured into the hitherto unpopular location area. Before long the location and its surroundings became a religious and educational centre for Salisbury Africans. (Yoshikuni 2007:38)

Religious denominations such as the Wesleyan Methodist Church, Salvation Army, Apostolic Faith Mission and the African Methodist Episcopal Church, among others, also opened up churches in the Church reserve. The Christian Church became an integral part of the life of the residents of the 'Location'. As the Township continued to grow and evolve, many churches were built outside the Church reserve 'by members of the various denominations through their own efforts' (Cormack 1983:15). However, lack of available space to build more churches, because of poor colonial planning, led many residents to content with making use of community halls, or school classrooms, and in dire circumstances, to conduct church services under trees (Cormack 1983:15).

By 1930, the 'African Location' had grown significantly. It now accommodated married residents.

According to Yoshikuni (2007:69), most of the occupiers of the married quarters were church people.

African churches and schools were allowed to integrate with the communities, within the 'Location', as opposed to the past when they were established at its outskirts. This practice continued into the 1940s and 1950s.

The critical role that the Church played in the development of Harare African Township is amply captured in the quotation below:

The provision of social services was at first left entirely to the churches and missionaries, who commenced their work soon after the start of the African urban settlement. Their activities covered areas of recreation, health and education, and much was done to develop and provide services for the African in town during the early part of the century. (Yoshikuni 2007:69)

Gradually, the Church became the most ubiquitous social organisation in the Township around which the spiritual life of the Township revolved. Although the primary purpose of the churches was to propagate the Christian faith, churches also engaged in humanitarian work. They also extended their service towards 'helping the sick, the bereaved, the destitute and aged members of their congregations and, where resources and facilities [permitted], to forming women's and youth clubs' (Cormack 1983:127-128). As the following sections will attest, Mai Musodzi and Sr Barbara Tredgold were two outstanding Christians who played a leading role in the life of the township.

\section{The life and times of Elizabeth Maria Ayema and Barbara Tredgold Elizabeth Maria Ayema (Mai Musodzi) (1885-1952)}

Penny (2017) describes Elizabeth Maria Ayema, popularly known as Mai Musodzi, as '... one of Zimbabwe's 100 most influential women of all time'. Musodzi Chibhaga was born in 1885 in the Mazowe valley; she was orphaned when her parents were victims of the scorched-earth reprisals launched by the BSAC Police during the 1896-1897 Shona risings. As a result, she sought refuge with her paternal aunt, who was married to chief Chinamhora. 'Since Chinamhora was in good books with the missionaries, it was arranged that Musodzi would go to school at Chishawasha primary school as a day scholar' (Ruzivo 2005:66). It was at Chishawasha Mission, run by the Jesuits, where Musodzi was baptised Elizabeth Maria.

In 1909, Elizabeth married Frank Joseph Kashimbo Ayema, a Lozi from Zambia, who worked as a policeman in Southern Rhodesia (Chikowero 2015:115). The Ayema family rented a cottage in Harare Township in the mid-1920s, and only became real 'residents' in the late 1930s (Yoshikuni 2007:8182). Apart from Elizabeth and Frank, some of their children who played memorable roles in the 'Township' were Francis Joseph and Moses. Not much, however, is remembered about Lucy, Luke and Raphael. As a recognition of the overall contribution of the family, residents of the 'Township' later renamed one of the streets as 'Ayema'.

In addition, another road in the 'National' section of the 'Township' was named after 'Francis Joseph Ayema'.

Within the scope of this article, it is not possible to cover each and every member of the Ayema family.

Hence, we will focus on Mai Musodzi who, as attested by many researchers, was the most exceptional member of the family. Like other researchers, we pay particular attention to her role and contribution to the development of 'Harare Township'.

Yoshikuni's monograph on Musodzi Ayema honours her as an exceptional lay Catholic leader and sees in her social commitment the beginnings of African feminism in early colonial Zimbabwe (Yoshikuni 2007:9).

Popularly known as 'Mai Musodzi', Mrs Elizabeth Maria Ayema was not only one of the oldest members at St. Peter's 
Parish, but became 'a key figure among the Catholic women, involved in charity and social welfare activities' (Yoshikuni 2007).

Ruzivo (2005:Online) presents a very illuminating picture of the respect that members of the lay Catholic sodality that she allegedly helped found, that is, Chita Cha Maria HosiYedenga (Mary Queen of Heaven), still have of her. The lay movement 'offered moral support to women who tried to maintain a decent family under difficult living conditions' in the Township (Hallencreutz 1998:15). Oral tradition on the founding of the lay movement places Mai Musodzi at the centre of its formation. Available oral sources argue that Elizabeth, and the other Catholic lay women who founded the sodality, had received their education from Chishawasha where they had been members of the Nzangaya Maria (i.e. Sodality of Our Lady of Heaven).

The sources claim that Mai Musodzi and her colleagues founded the movement with the support of Fr Adolf Hess (SJ) (Ruzivo 2005:Online). This tradition, however, differs from the official tradition contained in the handbook of the Chita Che HosiYedenga, which attributes Fr Alois Nyanhete, a diocesan priest, as the founder of the movement. Fr Nyanhete was Parish priest of St. Peter's for many years. Therefore, the official sources contradict and marginalise the role played by Mai Musodzi in the formation of the sodality.

Notwithstanding the divergent views raised by the two traditions, there is agreement that 'Mai Musodzi' was the inaugural Chairperson of the Chita Cha Maria HosiYedenga sodality. However, Ruzivo's attempt to reconcile the divergent sources needs some nuanced interpretation. He claims that:

There is no documentary evidence that clearly states that Fr Nyanhete was the originator of the movement. What is possible is that he could have been the catalyst in the development and expansion of the movement. (Ruzivo 2005:Online)

Ruzivo probably has in mind the onerous formalities that would have been needed for the sodality to get accepted and registered in the Archdiocese of Salisbury (now Harare). Such processes would definitely have required the guidance of a priest considering the hierarchical rigidity and patriarchal character of the Roman Catholic Church before Vatican II. My own research with women in Mbare confirms the version based on Oral Tradition. ${ }^{5}$ Interestingly, Hallencreutz (1998:215) supports this line of argument when he argues that the Chita Cha Maria HosiYedenga 'was inspired by Mai Musodzi' (Hallencreutz 1998:215).

Apart from her role in the founding of the Mary Queen of Heaven sodality, 'Mai Musodzi' started the first African Women's Home Craft Club in the 'Township'. The Club

5.See Interviews held with Mrs Kwedza and Mrs Vhuta at the new church, Mbare, National, 23 May 1991 (Personal interviews Mrs Vhuta, 23 May 1991 at the St Peter's Claver St Peter's Claver Roman Catholic Church [New Church], Mbare Township. Mrs Kwedza, 23 May 1991 at the St Peter's Claver Roman Catholic Church [New Church], Mbare Township). specialised in lectures addressing the plight of African women in the city (Hallencreutz 1998:215). Club members met regularly at the Harare Recreational Hall under Mrs Ayema's leadership. 'Mai Musodzi' became a legend in the 'Township' because of her industriousness, business acumen and charitableness. Decades after the demise of colonial rule, the recreational Hall has become 'one of the most notable historical buildings in Mbare'. ${ }^{6}$

'Mai Musodzi' also joined hands with Barbara Tredgold in forming Harare Township Red Cross Society (Chikowero 2015:115). The African weekly newspaper of 18 February 1948 has a photo of 'Mai Musodzi', receiving a Red Cross badge from Lady Kennedy, the President of the Red Cross in Rhodesia. In the article, 'Mai Musodzi' is described as the 'Commandant of the African Detachment, Salisbury Location' (Yoshikuni 2007:83).

Even before moving to the 'Location', 'Mai Musodzi' was known for her industriousness. Fr Burbidge S.J., who made submissions to the Morris Carter Commission on Land in Southern Rhodesia (1925), gave tribute to Mrs Ayema's enterprising farming success on her small piece of land on the Chizhanje farm, near Mabvuku Township, where she used to be a tenant. Fr Burbridge characterised Mai Musodzi as 'a torchbearer of Christian virtues ...' (Yoshikuni 2005:83). After moving into the 'Township', 'Mai Musodzi' was one of the very successful urban market gardening farmers on plots allocated to married residents in the Adbernie section of the 'Township'.

Apart from her farming acumen, 'Mai Musodzi' was 'a longtime advisor and negotiator in the township' (Scarnecchia 1999:160). In recognition of her sterling work and exceptional Christian leadership, her funeral in 1952 was attended by City Council Officials and top journalists. One of the leading journalists of the time, Lawrence Vambe, depicted 'Mai Musodzi' as the 'Queen of Salisbury' (Scarnecchia 1999:160). In 1982, in recognition of her illustrious life as an 'influential Community leader' in the township, residents of the township renamed the former Harare Township Recreational Hall, built in 1935, as Mai Musodzi Hall (Chikowero 2015:115)

\section{Barbara Tredgold (1905-unknown)}

Barbara Tredgold was born in 1905 in Southern Rhodesia. She was a daughter of Clarkson Henry Tredgold and Henry Ruth Smith Tredgold, and was the great-niece of Mary Moffat (wife of Robert Moffat). She was also sister to Sir Robert Tredgold, one-time Chief Justice of Southern Rhodesia. Blanchard (2009:31-32) categorises her as one of the 'blue Rhodesians', that is Rhodesians who were 'not recent immigrants but long standing immigrants or born and bred'.

Official Minutes of the Proceedings of the Southern Rhodesia Missionary Conference always use the title 'Miss' 6.<http://self.gutenberg.org/articles/mbare>, accessed on $09 / 08 / 2015$. 
when referring to her. ${ }^{7}$ However, both Hallencreutz (1998:59) and Christie (1994:621) refer to her as 'Sister', possibly implying that she was an Anglican nun. In a book written to honour 'Women leaders of Tropical Africa', Nora Thompson (1963:6) calls Barbara 'an Anglican missionary' who served many years at Runyararo, Harare Township. Considering the fact that she was born in Rhodesia, it is difficult to understand her missionary status to say that she was a white person appointed to work and live in an African Township (Christie 1994:621). In a country that saw everything in terms of race, and where colour bar was the norm, the authorities only granted Barbara permission to live in an African Township 'after a long considerable correspondence' (Christie 1994:621).

According to Mungazi (1996:123), Barbara's passion was 'promoting the development of African women'.

She was instrumental in establishing Runyararo Hostel, the only shelter for young rural African women who had found employment in Salisbury. Barbara was the leader of Runyararo Community, which was established in Mbare in 1946. Apart from her primary role at Runyararo, she was also involved in a myriad of activities and projects aimed at women empowerment. With four co-workers, Barbara did social work in Mbare and Highfields townships. She also ran a nursery school comprising 200 children of working mothers at St. Michael's Church. Barbara had other responsibilities at St. Michael's parish that included helping in the church and mission activities, 'particularly in training the Africans to take charge ...' (Thompson 1963:11).

Apart from St. Michael's church, Barbara played a critical role in introducing the Red Cross Society to Harare Township. She worked closely with 'Mai Musodzi', Mrs Lucy Chabuka (Elizabeth Musodzi's daughter) and others. She also played the role of advisor to the leadership of the Home Craft movement in Southern Rhodesia (West 2002:7). Mungazi (1996:123) notes that Barbara '... was resented to [sic] the colonial government' because of her service as a fearless leader, who worked as an advocate for the cause of African women.

Moreover, Barbara became a founder member of the InterRacial Association of Southern Rhodesia (IASR), which was launched by her brother, Sir Robert Tredgold, the then Chief Justice of Southern Rhodesia, on 25 July 1953 (Hancock 1984:11). Some of the leading black nationalists whom she worked alongside include Moses Ayema, Chad Chipunza, Nathan Shamuyarira, Stanlake Samkange, among others. Blanchard (2009:31) contends that Barbara belonged to a group of Rhodesians whose outlook was: 'We're in this together, we have got to look after each other and that included blacks'. Blanchard (2009) is, however, not oblivious to the paternalism that was endemic in the Inter-Racial Association of Salisbury. Hence, he is quick to defend the 7.See Minutes of the Proceedings of Southern Rhodesia Missionary Conference, 1952, $<$ www.archive.org/details/proceedings of sou1952souts. likes of Barbara Tredgold as not 'as virulently aggressive as these jokers from the Rhodesia Front'.

Alongside Mai Musodzi, Barbara worked closely with the African Ministers' Fraternal in the fight against the immoral mahobho dances in Harare Township (Hallencreutz 1998:332). She was at the centre of what Vambe (2007) calls:

... the struggle to domesticate the city, to make it work for black women economically ... [that] manifested itself in the desire to engage with African notions of respectability, acceptability and the refusal to be considered dirty. (pp. 355-369)

Because of her distinguished role in the Parish of St. Michaels, Barbara developed an intimate relationship with the citizens of Harare Township.

In keeping with her role as a 'missionary to Africans', Barbara was an active member of the Executive Committee of the Southern Rhodesia African Missionary Conference (SRAMC), for many years. At the 1952 Conference she moved a motion urging municipalities in the country to build hostels for working African girls. The motion received a hearty approval. So was the motion on the need to provide church sites in native urban areas. ${ }^{8}$

Politically, Barbara was a pacifist who believed in a nonviolent struggle against Smith's Unilateral Declaration of Independence (UDI) and the Rhodesia Front's policies of segregation against black people.

Evidence points to her being a supporter of Abel Muzorewa's United African National Council (UANC), in the late 1970s. She was equally opposed to the violence perpetrated against rural peasants by both the Rhodesian soldiers and the 'Freedom Fighters' (Moyo 2015:170).

In 1982, citizens of Harare Township acknowledged the sterling service that Barbara had rendered to the 'Township' by naming a street in her honour. The Barbara Tredgold circle is situated in the vicinity of St. Michael's Anglican Church, and in the section known by many as 'National'.

\section{Conclusion}

Although place naming is fundamentally political and ideological, it is important for Church historians to excavate the role of the church in such discourses. In the case of Harare Township, renamed Mbare in 1982, we acknowledge that the honour bequeathed by the residents on the two women leaders, discussed above, is a public affirmation of the central role that the Church and Christian values played in shaping the life and ethos of the 'Township'. By renaming the Harare Recreational Hall and a street in honour of the two heroines, residents of Mbare affirmed and inscribed the presence of Christian values in the development of the 'Township'.

8.Minutes of the Proceedings of the Southern Rhodesia African Missionary Conference. 
Through the process of place naming, the politics of identity and self-representation were being deployed.

As much as naming has to do with how one interprets the past, we acknowledge that it was also a way of projecting the past into the suburb's vision of the future. By acknowledging the roles of 'Mai Musodzi' and Barbara Tredgold, the community of Mbare effectively laid claim to a Christian ethos that helped shape their experiences of the Township. Through the process of renaming, they were thus making a commitment to remembering 'Mai Musodzi' and Barbara Tredgold as signposts of exemplary civic and religious leadership that they would have wanted to see in postcolonial Zimbabwe.

The religious organisations or institutions associated with 'Mai Musodzi' and Barbara Tredgold continue to define the social and spiritual horizons of Mbare Township. Notably, the Chita Cha Maria Hosi ye Denga [Sodality of Mary Queen of Heaven], that 'Mai Musodzi' founded/co-founded and was the inaugural leader of, continues to thrive. Decades after the passing of 'Mai Musodzi', St. Peter's Parish, Mbare, continues to be the centre and home of the Chita Cha Maria HosiYedenga in Mbare Township. Similarly, Runyararo, situated within St. Michael's Parish, Mbare, continues to provide a physical home and a social and spiritual sanctuary to young African women. Undoubtedly, the legacies of 'Mai Musodzi' Ayema and Barbara Tredgold continue to subsist in the psyche of residents of Mbare. Hence, the Hall and street that were named/renamed after the two heroines continue to function as a signpost of the legacy, vision and ideals epitomised in their lives of dedicated service. For these reasons, it would not be presumptuous to argue that the honour bestowed on 'Mai Musodzi' and Barbara Tredgold effectively makes them 'Church Mothers' of the Mbare Christian community.

As Mushati (2013) observes, the renaming of colonial street names and names of buildings indeed offers an ideal platform to formerly colonised subjects, who had been erased from history, to engage in counter-discourse that authorise their presence - in a new political dispensation under a black government'. Their hope for change was predicated on values and ethos of emancipation represented by their heroes and heroines, who included 'Mai Musodzi' and Barbara Tredgold. The renaming process also helped residents of Mbare to transform the negative sense of place into a positive one (Guyot \& Seethal 2012). At the heart of the process is the need to signal 'a significant change in social direction for individual and collectivity' (Feraco \& Murphy 1997).

\section{Acknowledgements Competing interests}

The author declares that he has no financial or personal relationships that may have inappropriately influenced him in writing this article.

\section{References}

Blanchard, A., 2009, Rhodesian forces oral history project, University of the West of England, Bristol, viewed 28 August 2015, from www://eprints.uwe.ac.uk/11455

Chikowero, M., 2015, African music, power and being in colonial Zimbabwe, Indiana University Press, Bloomington, IN.

Christie, R.H., 1994, 'Recollections of the Rhodesian bench and bar some forty year ago', South African Law Journal 619, 619-625.

Cormack, I.R.N., 1983, Towards self-reliance, urban social development in Zimbabwe, Mambo Press, Gweru.

Faraco, G.C. \& Murphy, M.D., 1997, 'Street names and political regimes in an Andalusian town', Journal of Ethnology 36(2), 123-148. https://doi.org/10.2307/3774079

Guyot, S. \& Seethal, C., 2012, 'Identity of place, places of identities: Change of place names in post-apartheid South Africa', South African Geographical Journal 89(1) 55-63, viewed 09 August 2015, from http://self.gutenberg.org/articles/mbare

Hallencreutz, C.F., 1998, Religion and politics in Harare 1890-1980, Swedish Institute of Missionary Research, Uppsala.

Hancock, I., 1984, White liberals, moderates and radicals in Rhodesia 1953-1980, Croom Helm, London.

Jenje-Makwenda, J., 2011, 'Street names not mere signposts', The Herald, 10 August, viewed 27 August 2016, from http://www.herald.co.zw/street-names-not-meresignposts/

Kadirire, H., 2014, 'Behind Mbare street names', The Weekend Post, 10 February, viewed 07 November 2015, from http://www.weekendpost.co.zw/articles/2014/

Makombe, E.K., 2013, 'A social history of town and country: A study on the changing social life and practices of rural-urban migrants in colonial Harare and Goromonzi (1946-1979)', PhD thesis, University of the Witwatersrand, Johannesburg.

Minutes of the Proceedings of the Southern Rhodesia African Missionary Conference (SRMC), 1952, Southern Rhodesia African Missionary Conference, viewed 16 August 2015, from www.archive.org/details/proceedings of sou1952sout

Moyo, F., 2015, The Bible, the bullet and the ballot, Pickwick Publications, Eugene, OR.

Mungazi, D. 1996, The mind of Black Africa, Praeger, Westcourt, CT.

Mushati, A., 2013, 'Street naming as author(is)ing the collective memory of the nation', Journal of Asian Social Science 3(1), 69-91.

Penny, B., 2017, 'The life and times of Mai Musodzi', News Day, 10 August, viewed 02 November 2017, from http://www.newsday.co.zw/20172017/08.life-timesmai-musodzi/

Rakodi, C., 1995, Inheriting a settler-colonial city: Change and continuity, John Wiley \& Sons, Harare.

Ranger, T.O., 2013, Writing Revolt, an engagement with African Nationalism 1957-67, Weaver Press, Harare.

Ruzivo, M., 2006, 'Elizabeth Musodzi: The Catholic woman agent of the Gospel', Studia Historiae Ecclesisticae xxxi (2), 63-75.

Scarnecchia, T., 1999, 'The mapping of respectability and transformation of African residential space', in B. Raftopoulos \& T. Yoshikuni (eds.), Sites of struggles essays in Zimbabwean urban history, pp. 151-162, Weaver Press, Harare.

Thompson, N.B. (ed.), 1963, 'Vignettes of Women in Africa', Africa to me: Some women leaders of tropical Africa, pp. 5-14, Candor Press, Chicago, IL.

Vambe, M.T., 2007, “'Ayamahobo": Migrant labour and the cultural semiotics of Harare (Mbare) African Township, 1930-70', African Identities 5(3), 355-369. https://doi.org/10.1080/14725840701611455

West, M., 2002, The rise of an African Middle class: Colonial Zimbabwe, 1899-1965, Indiana University Press, Bloomington.

Yoshikuni, T., 2007, African urban experiences in colonial Zimbabwe; A social history of Harare before 1925, Weaver Press, Harare. 